ISSN 1991-8631

Original Paper

http://indexmedicus.afro.who.int

\title{
Effects of farmers' practices of fertilizer application and land use types on subsequent maize yield and nutrient uptake in central Benin
}

\author{
Aliou SAIDOU ${ }^{1,3^{*}}$, Dansou KOSSOU ${ }^{1}$, Charles ACAKPO ${ }^{1}$, Paul RICHARDS ${ }^{2}$ and \\ Thomas W. KUYPER ${ }^{3}$ \\ ${ }^{I}$ Projet Convergence des Sciences, Faculté des Sciences Agronomiques, \\ Université d'Abomey-Calavi, 01 BP 526 RP Cotonou, Benin. \\ ${ }^{2}$ Technology and Agrarian Development (TAO) Group, Wageningen University, \\ Hollandseweg 1, 6706 KN Wageningen, The Netherlands. \\ ${ }^{3}$ Department of Soil Quality, Wageningen University, Droevendaalsesteeg 4 NL-6708 PB Wageningen; \\ P.O. Box 47 NL-6700 AA Wageningen, The Netherlands. \\ *Corresponding author, E-mail: saidoualiou@gmail.com
}

\begin{abstract}
Four on-farm experiments in central Benin examined whether land-use succession and fertilizer treatments for prior cotton would sustain subsequent maize crop yields and achieve balanced plant nutrition. Treatments consisted of three prior land use successions, i.e. before planting maize (egusi melon-cotton-cottonmaize, cotton-maize-cotton-maize and cassava-maize-cotton-maize) including for each, four replications of three fertilizer treatments: recommended practice [150 $\mathrm{kg} \mathrm{ha}^{-1}$ of 14-23-14 (NPK) plus 5S-1B, applied 25 days after sowing and $50 \mathrm{~kg} \mathrm{ha}^{-1}$ of urea on 40 days after sowing], NPK-SB mixed with urea (the recommended amount of NPK-SB and urea are mixed then applied 40 days after sowing) and reduced NPK-SB dose (recommended practice, but the amount of NPK-SB is reduced to $100 \mathrm{~kg} \mathrm{ha}^{-1}$ ). Prior cotton and subsequent maize yields and nutrient uptake were not significantly affected by fertilizer treatments. Furthermore, fertilizer treatments had no significant effect on soil chemical properties before planting the subsequent maize crop. Land use types had significant effect on cotton yields, soil chemical properties, subsequent maize yields and nutrient uptake. The lowest yield and nutrient uptake were registered in the cotton-maize-cotton-maize land use succession and the highest in the egusi melon-cotton-cotton-maize succession. For sustainable soil fertility management, adoption of adequate crop succession system and recommended fertilizer application practice are suggested.
\end{abstract}

(C) 2012 International Formulae Group. All rights reserved.

Keywords: Crop rotation, technology adaptation, soil fertility, residual effect, maize cultivation, balanced nutrition.

\section{INTRODUCTION}

Agricultural production is for the majority of the West African rural population the major source of income in a rural livelihood portfolio that often includes other activities. Continuous cultivation without adequate replenishment of the natural resource base leads to soil degradation including nutrient depletion, representing a serious threat to sustained agricultural productivity (Saïdou et al., 2003). Technologies associated with the 'Green Revolution' that rely purely 
on substantial use of mineral fertilizer have failed to take hold in Africa (Giller, 2002) due to problems related to the cost and availability of inputs. Access to mineral fertilizers in rural areas has been considerably affected by introduction of structural adjustment programs requiring liberalisation of input delivery services (Vanlauwe and Giller, 2006). Such situation lead farmers to have stronger incentive to determine carefully the usage of mineral fertilizer, and this appear to have guided adaptation of mineral fertilizer technology by minimizing fertilizer input.

The incentive to use fertilizer more costeffectively fits into a larger context for change within farming systems in central Benin in recent decades. Land is now more frequently cropped, in response to a range of external drivers. In this area, mineral fertilizer is mainly used for cotton, the country's main cash crop. Mostly in the cotton growing areas, mineral fertilizer is available for cotton in disadvantage of food crops, especially maize. Farmers who are aware of fertilizer residual effect, introduced cotton rotation with maize in order to enhance the cereal production through the residual effect of fertilizer applied for preceding cotton (Saïdou et al., 2004).

Farmers in the West African cotton belt (Fok et al., 2000) - and Benin is no exception - appear to be skilled in adapting fertilizer application practices. Instead of following the recommended practice, they slightly reduce the amount of NPK or mix NPK and urea fertilizers (Saïdou et al., 2004). The practices are guided by economic incentives; both the need to reduce labour inputs (i.e. to reduce labour costs in the case of mixing fertilizers) and the need to reduce cash outlays (fertilizer input is delivered as credit so farmers reduce the quantity of fertilizer used and increase margins when they sell their cotton). Because nitrogen is easily lost under tropical conditions (Oikeh et al., 2003) through volatilisation and leaching these novel practices may have adverse effects in terms of subsequent food crop yields. Furthermore, P and $\mathrm{K}$ can be leached and immobilized in tropical soils (Koné et al., 2010a) limiting their availability to subsequent crop. Therefore, the current practice needs to be guided by identifying threshold level of minimum rate of fertilizer.

We investigated the extent to which farmers' knowledge of nutrient management practices in cotton-based farming systems can sustain yields of prior cotton and a subsequent maize crop. The research aimed: (i) to assess the effect of fertilizer treatments and land use successions on soil chemical properties before planting a subsequent maize crop, (ii) to determine the response of cotton and a subsequent maize crop to fertilizer application practices and land use types and finally (iii) to determine the amount of nutrient taken up by the subsequent maize crop regarding the land use types and fertilizer application practices.

\section{MATERIALS AND METHODS}

\section{Study site}

The study was carried out in farmers' fields at Ouoghi central village $\left(8^{\circ} 07^{\prime} \mathrm{N}\right.$, $\left.2^{\circ} 33^{\prime} \mathrm{E}\right)$ in the transitional agro-ecological zone of Benin. The area is at an altitude of about $200 \mathrm{~m}$ a.s.l. It has a Sudano-Guinean climate with a unimodal rainfall pattern. Average annual rainfall and temperature (from 1990 to 2005 ) are $1100 \mathrm{~mm}$ and $27.5^{\circ} \mathrm{C}$, respectively. Rainfall at the site lasts from April to mid-November. The soil is dominated by tropical ferruginous soils (Dubroeucq, 1977) derived from Precambrian crystalline rocks (granite and gneiss as parent material), and classified as Ultisols according to the Soil Taxonomy (Soil Survey Staff, 1992). Soil particle size and chemical properties at the beginning of the experiment are presented in Table 1.

\section{Experimental set up}

The on-farm experiment was carried out under farmers' condition. Three fields were selected with regard to previous land use types, i.e., the cropping sequences widely practised in the area. Each field represented a specific cropping sequence before planting maize: (1) egusi melon-cotton-cotton; (2) cotton-maize-cotton and (3) cassava-maize- 
cotton. Planting, weeding, harvesting and frequency of weeding operations were left up to each farmer. The researcher provided only maize seeds. Two weeding operations were carried out in each field.

The cotton was sole planted in July 2002 and harvested on January 2003. For each field (corresponding to a cropping sequence), the experiment was set up according to a completely randomised bloc design with three treatments consisting of farmers' practices of fertilizer application. Each treatment was replicated four times (pseudo-replication, i.e. replication within a field). There was no replication of fields, because it was difficult to find fields with the same history and management type for comparison. The recommended rate of fertilizer was the control treatment. The three treatments were:

(1) recommended practice (control), $150 \mathrm{~kg}$ $\mathrm{ha}^{-1}$ of 14-23-14-5-1 (NPK-SB) applied (in a hole at $5 \mathrm{~cm}$ to the plant then closed in other to avoid loss through volatilization) to cotton 25 days after sowing (DAS) and $50 \mathrm{~kg} \mathrm{ha}^{-1}$ of urea applied 40 DAS; the amount of macronutrients applied were: $51 \mathrm{~kg} \mathrm{~N} \mathrm{ha}^{-1}$, $15.2 \mathrm{~kg} \mathrm{P} \mathrm{ha}^{-1}$ and $17.4 \mathrm{~kg} \mathrm{~K} \mathrm{ha}^{-1}$;

(2) NPK-SB mixed with urea (the recommended amounts of NPK-SB and urea were mixed and then both applied 40 DAS);

(3) Reduced amount of NPK-SB (100 kg ha 1) $25 \mathrm{DAS}$ and $50 \mathrm{~kg} \mathrm{ha}^{-1}$ of urea applied 40 DAS; the amounts of macronutrients applied were: $44 \mathrm{~kg} \mathrm{~N} \mathrm{ha}^{-1}, 10.1 \mathrm{~kg} \mathrm{P} \mathrm{ha}^{-1}$ and 11.6 $\mathrm{kg} \mathrm{K} \mathrm{ha}{ }^{-1}$.

Plot size was $100 \mathrm{~m}^{2}(10 \mathrm{~m} \times 10 \mathrm{~m})$; the harvest area was $64 \mathrm{~m}^{2}(8 \mathrm{~m} \times 8 \mathrm{~m})$. The prior cotton plant spacing was $0.2 \mathrm{~m} \times 0.8 \mathrm{~m}$ with two plants per hole. Cotton fibre and stalks were assessed and sub-samples were collected and weighed. Dry matter was determined after drying at $60^{\circ} \mathrm{C}$ for $48 \mathrm{~h}$. The experimental unit concerned the fertilizer treatment plot instead of the land use type factor. Composite soil samples were collected at a depth of $0-20 \mathrm{~cm}$ in each field before planting the subsequent maize. In total, 9 soil cores were collected in each plot following the plot width.
The subsequent maize crop was cultivated in accordance with farmers' practices, i.e., without further fertilizer input. In each land use type, the plots were deeply plough manually before establishing the experimental design. Seeds of an early maturing (3 months cycle) maize cultivar, DMR-SRW, provided by the extension service, were sown in May 2004 according to farmers' practices. Plant spacing was $0.7 \mathrm{~m} \mathrm{x}$ $0.8 \mathrm{~m}$ with two plants per hole. Maize was harvested at physiological maturity in August 2004. Maize cobs and straw plus husk and grain weights were recorded in the field with a scale. Samples of straw plus husk, and grain were taken, weighed and the dry matter was determined after oven drying at $60^{\circ} \mathrm{C}$ for $48 \mathrm{~h}$ to a constant weight. These samples were ground in a stainless steel mill in order to perform analysis of macronutrients.

\section{Soil and plant chemical analyzes}

Soil and plant chemical analyzes were performed in the Laboratory of Soil Sciences of the Faculté des Sciences Agronomiques of the University of Abomey-Calavi. Soil analyses were carried out on $\mathrm{pH}$ (water) (using a glass electrode in 1:2.5 v/v soil solution), total $\mathrm{N}$ (Kjeldahl digestion in a mixture of $\mathrm{H}_{2} \mathrm{SO}_{4}$-Selenium followed by distillation and titration), available $\mathrm{P}$ (Bray 1 method), exchangeable $\mathrm{K}^{+}$(with $1 \mathrm{~N}$ ammonium acetate at $\mathrm{pH} 7$, after which $\mathrm{K}^{+}$ was determined by flame photometer), $\mathrm{NO}_{3}{ }^{-}$$\mathrm{N}$ and $\mathrm{NH}_{4}{ }^{+}-\mathrm{N}$ in $1 \mathrm{M} \mathrm{KCl}$ extract $\left(\mathrm{NO}_{3}{ }^{-}-\mathrm{N}\right.$ after adding $\mathrm{MgO}$ and distilling the mixture followed by titration; $\mathrm{NH}_{4}{ }^{+}-\mathrm{N}$ by adding to the preceding mixture Devarda alloy after which the new mixture was distilled followed by titration).

Total $\mathrm{N}$ in the plant tissue (grain and stover plus husk) was analyzed by wet digestion in a mixture of $\mathrm{H}_{2} \mathrm{SO}_{4}$-Selenium followed by distillation and titration. $\mathrm{K}$ was measured in the extract by flame photometer. Determination of $\mathrm{P}$ included two steps, dry ashing a plant sample in a muffle furnace at $550^{\circ} \mathrm{C}$ for $4 \mathrm{~h}$ and gathering the residues in $1 \mathrm{~N}$ $\mathrm{HNO}_{3}$ involving a period of heating. 
Table 1: Soil $(0-20 \mathrm{~cm})$ chemical and physical properties at the beginning of the experiment regarding the previous crop rotation types before cultivating cotton.

\begin{tabular}{|c|c|c|c|c|c|c|c|}
\hline Land use types & Clay & $\frac{\text { Silt }}{(\%)}$ & Sand & $\begin{array}{l}\text { pH } \\
\text { (water) }\end{array}$ & $\begin{array}{l}\text { N-total } \\
\left(\mathrm{g} \mathrm{kg}^{-1}\right)\end{array}$ & $\begin{array}{l}\text { P-Bray 1 } \\
\left(\mathrm{mg} \mathrm{kg}^{-1}\right)\end{array}$ & $\begin{array}{l}\text { Exch. K }{ }^{+} \\
\left(\mathbf{c m o l ~ k g} \mathbf{~ g}^{-1}\right)\end{array}$ \\
\hline Egusi-cotton-cotton & 4 & 11 & 85 & 6.6 & 0.8 & 16.4 & 0.3 \\
\hline Cotton-maize-cotton & 5 & 10 & 85 & 6.6 & 0.9 & 21.0 & 0.4 \\
\hline Cassava-maize-cotton & 2 & 12 & 86 & 6.5 & 1.2 & 16.8 & 0.2 \\
\hline
\end{tabular}

Phosphorus was subsequently measured by colorimeter using ammonium molybdate with ascorbic acid at a wavelength of $660 \mathrm{~nm}$.

The total nutrients $(\mathrm{N}, \mathrm{P}$ and $\mathrm{K})$ taken up by the maize plants concerned nutrients removal through the harvested products (grain) and that of the stover plus husk. The uptake was estimated by multiplying nutrient concentration in the grain and the stover plus the husk by the total production of the grain and the stover plus husk.

\section{Statistical analyses}

Statistical analyses were performed using the SAS v 8.1 package. Soil chemical properties, yield parameters (cotton fibre, cotton stalks, grain and stover mass), macronutrient concentration in the plant tissue, and nutrient uptake, were subjected to nested analysis of variance (analysis based on an hierarchical classification model of Cochran (1967)) regarding land use types and fertilizer treatments. This analysis was performed following the GLM procedure. Such nested designs arise in situations where replicate measurements are made on the same experimental unit. They superficially resemble randomized blocks designs but require alternative methods of analysis because the levels of the second factor (in this case cropping sequence before planting maize) are not common to all treatments. The Student Newman-Keuls test was performed to compare differences in means among treatments and also among land use types. All significance levels were set at $P<0.05$.

\section{RESULTS}

Effect of land use types and fertilizer
application practices on soil chemical
properties

Apart from $\mathrm{NH}_{4}-\mathrm{N}$ and $\mathrm{NO}_{3}-\mathrm{N}$, soil chemical properties before planting the maize crop were significantly $(0.01<\mathrm{P}<0.05)$ affected by the land use types (Table 2a). Soil $\mathrm{pH}$ was significantly $(\mathrm{P}<0.05)$ higher in the egusi melon-cotton-cotton-maize field than that of cotton-maize-cotton-maize field (Table 2b). Total $\mathrm{N}$ and available $\mathrm{P}$ were significantly $(\mathrm{P}<0.05$ and $\mathrm{P}<0.01$ respectively) higher in the cassava-maizecotton-maize and cotton-maize-cotton-maize fields compared to the egusi melon-cottoncotton-maize field. Exchangeable $\mathrm{K}^{+}$in the cotton-maize-cotton-maize field was significantly $(\mathrm{P}<0.01)$ higher compared to that of cassava-maize-cotton-maize and egusi melon-cotton-cotton-maize fields. Both $\mathrm{NH}_{4^{-}}$ $\mathrm{N}$ and $\mathrm{NO}_{3}-\mathrm{N}$ concentrations in the soil were not significantly $(\mathrm{P}>0.05)$ affected by land use types.

In general, the fertilizer treatments had no significant effect $(\mathrm{P}>0.05)$ on soil chemical properties before planting the subsequent maize crop. Plots of the recommended practice showed somewhat higher soil available $\mathrm{P}$ for Egusi-cottoncotton-maize and cotton-maize-cotton-maize land use types.

\section{Effects of land use types and fertilizer treatments on cotton yields}

The cotton fibre plus seed yield was significantly $(\mathrm{P}<0.01)$ affected by land use types. Fertilizer treatments did not affect 
significantly $(\mathrm{P}>0.05)$ the cotton fibre and seed yield and stalk mass (Table 3). The cotton fibre and seed yield and stalk mass regarding the three land use types and fertilizer treatments are presented in Figure 1. The overall means regarding the land use types indicated that cotton fibre and seed mass in the egusi melon-cotton-cotton field was almost 1.5 times significantly higher than that in the cassava-maize-cotton field.

Cotton fibre and seed mass ranged between 1.1 to $2.0 \mathrm{t} \mathrm{DM} \mathrm{ha}^{-1}$ for all three fertilizer treatments. Stalk mass followed a similar trend. The quantity of stalk mass ranged between 4.5 to $6.2 \mathrm{t} \mathrm{DM} \mathrm{ha}^{-1}$ for all three fertilizer treatments.
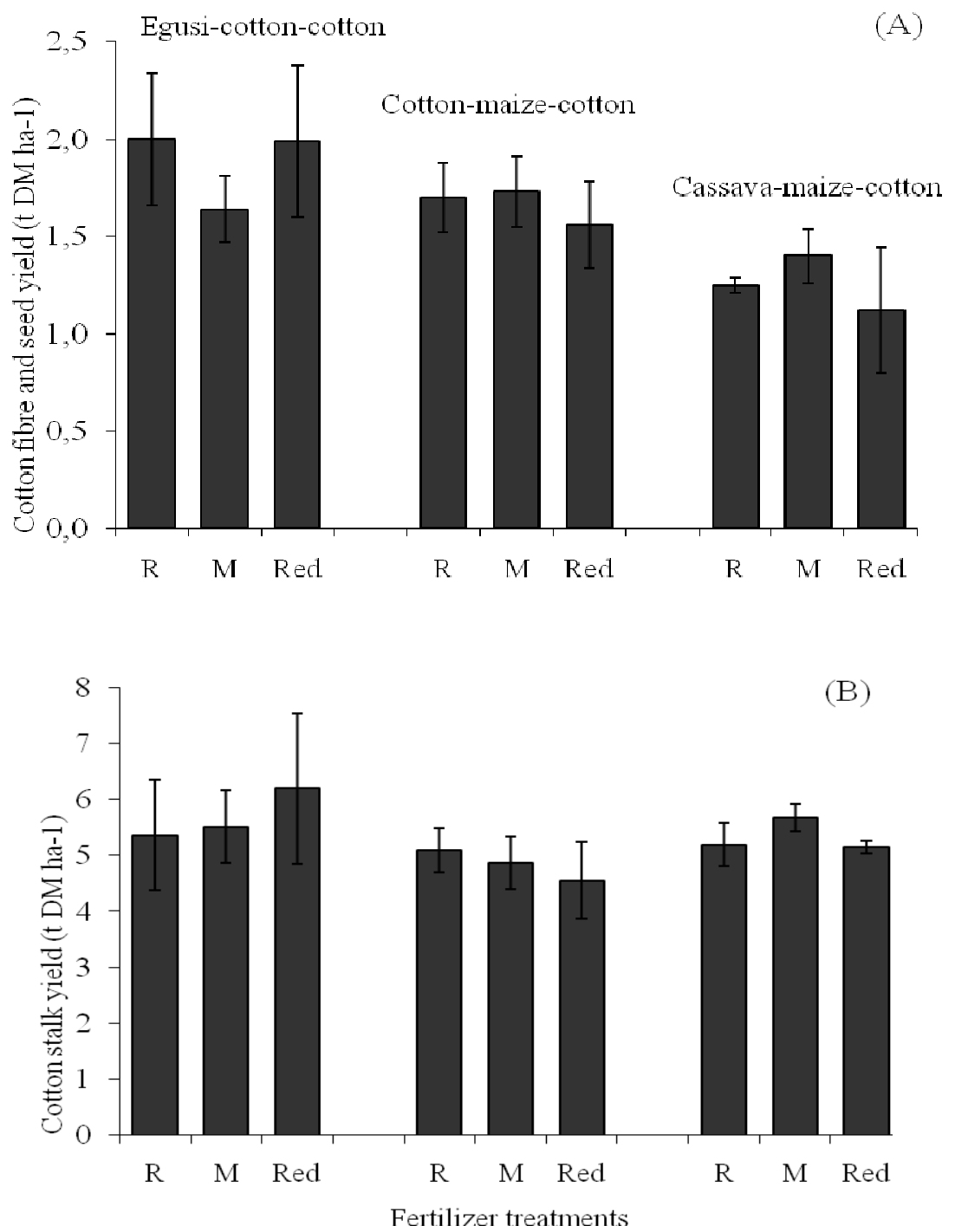

$\mathrm{R}=$ Recommended fertilizer application practice $; \mathrm{M}=\mathrm{NPK}-\mathrm{SB}$ mixed with urea practice. Red. $=$ Reduction of NPK-SB dose plus urea (split as recommended practice).

Figure 1: Cotton fibre and seed yield (A) and stalk mass (B) regarding fertilizer treatments and land use types. Vertical bars denote standard errors. 
Effect of land use types and fertilizer treatments on the succeeding maize crop yield and nutrient uptake

Table 4 presents the results of the nested ANOVA of the subsequent maize yield regarding land use types and prior fertilizer treatments. Maize grain and stover yields were significantly $(\mathrm{P}<0.01$ and $\mathrm{P}<0.05$ respectively) affected by land use types whereas, prior fertilizer treatments did not have a significant $(\mathrm{P}>0.05)$ effect on maize yields.

Figure 2 shows the mean values of the subsequent maize grain and stover yields regarding the prior fertilizer treatments and land use types. Grain yields ranged between
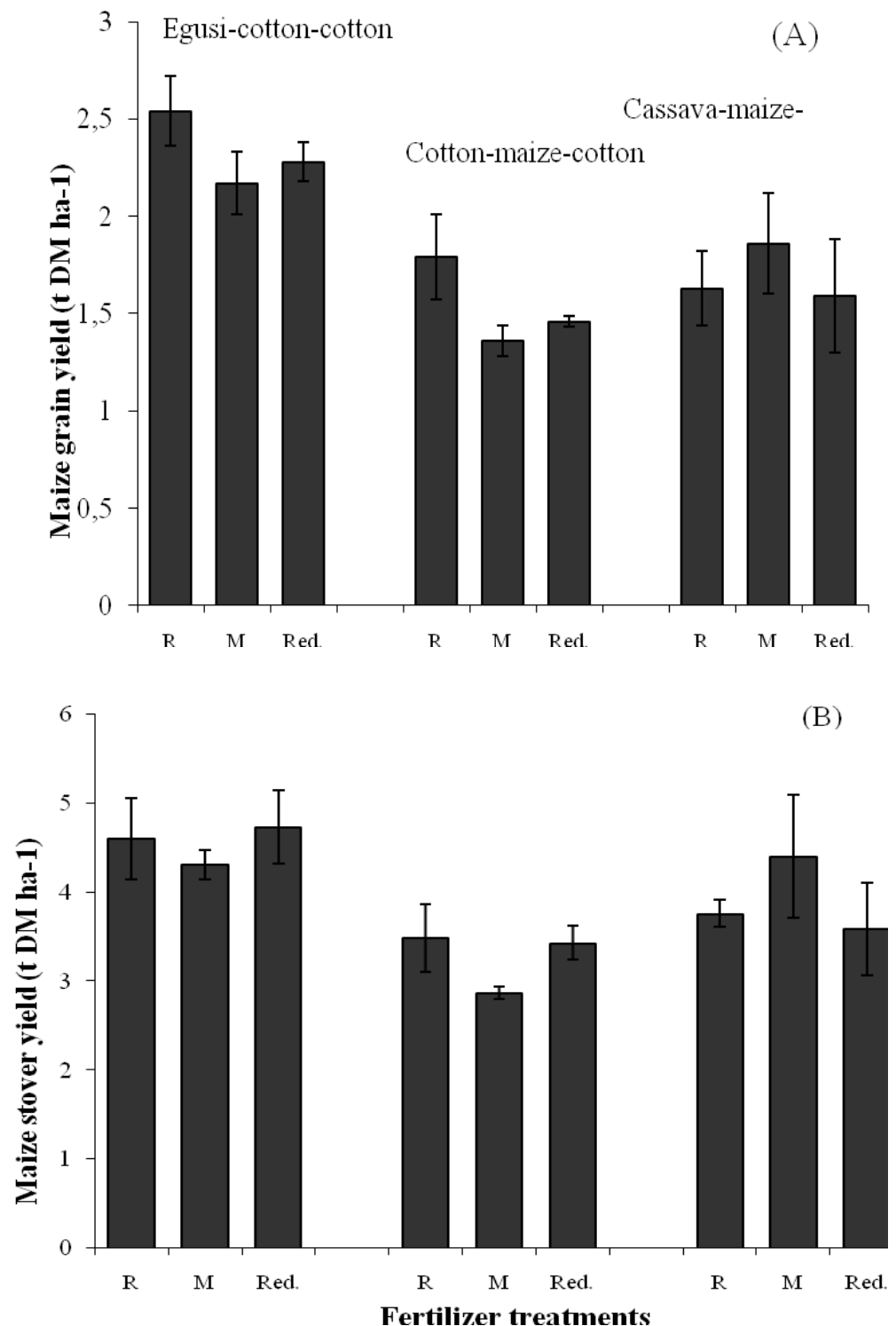

$\mathrm{R}=$ Recommended fertilizer application practice $; \mathrm{M}=$ NPKSB mixed with urea practice; Red. = Reduction of NPKSB dose plus urea (split as recommended practice).

Figure 2: Subsequent maize grain (A) and stover (B) yields regarding fertilizer treatments and land use types. Vertical bars denote standard errors. 
1.4 and 2.5 t DM ha ${ }^{-1}$ for all fertilizer treatments. Grain yields were highest in the egusi-cotton-cotton-maize field (2.3 t DM $\mathrm{ha}^{-1}$ ) and lowest in the Cotton-maize-cottonmaize field (1.5 t DM ha-1). Maize stover showed the same pattern of being highest in the egusi-cotton-cotton-maize field and lowest in the cotton-maize-cotton-maize field.

Table 5a presents the results of the nested ANOVA nutrient concentration for grain and stover and the total nutrient uptake. Land use types also affected significantly nutrient concentrations of maize grain $(\mathrm{N}, \mathrm{P}$, $\mathrm{K})$ and stover $(\mathrm{P}, \mathrm{K})$ as well as the total $\mathrm{N}$ uptake. Prior fertilizer treatment was not a significant source of variation. Nutrient analysis of the grains indicated that the nitrogen concentration in the cassava-maizecotton-maize field was significantly lower than that of the other fields and phosphorus concentration was significantly lower in the egusi-cotton-maize-maize field than in the other fields. Potassium concentration was significantly higher in the cassava-maizecotton-maize field than in the others (Table $5 b)$. Total nitrogen uptake was highest in the egusi-cotton-cotton-maize field and lowest in the other fields, consistent with data on grain yield.

\section{DISCUSSION \\ Soil characteristic regarding fertilizer treatments and land use types}

Our study clearly showed that, only the land use types (i.e. the previously grown crops) affected much more soil total $\mathrm{N}$, available $\mathrm{P}$ and the exchangeable $\mathrm{K}$ than the fertilizer application practice. This is important when cotton has been previously grown twice. Such result could be explained by the positive effect of the cotton (as it is the only crop which benefit mineral fertilizer) on the soil due to the residual effect of certain nutrient especially P (Van der Eijk, 2006). In fact, phosphorus may either stay in the soil and result in carry-over effects to the next crop or be lost by leaching or run off or fixed by oxide and hydroxide as usually occurring in the tropical acid soil (Koné et al., 2009 ; Koné et al., 2010b).

The timing of $\mathrm{N}$ application (splitting practice), as recommended by the extension service, is in fact a strategy to reduce nutrient loss, compared with farmers' practice (mixing NPK-SB and urea). However, both $\mathrm{N}$ fractions $\left(\mathrm{NH}_{4}-\mathrm{N}\right.$ and $\left.\mathrm{NO}_{3}-\mathrm{N}\right)$ in the soil before planting the subsequent maize were not different regarding the fertilizer application practices. We expected a significant difference between the splitting practice and the one time mixing practice application, but such an effect was neither discovered.

Table 2a: Nested analysis of variance (F-values) of soil chemical properties before planting the subsequent maize crop regarding fertilizer treatments (FAP) for prior cotton crop and land use types (LUT). Figures in parentheses are probabilities of F-values.

\begin{tabular}{llllllll}
\hline $\begin{array}{l}\text { Source of } \\
\text { variation }\end{array}$ & df & pH (water) & Total N & P-Bray 1 & Exch. $\mathbf{K}^{+}$ & $\mathbf{N H}_{\mathbf{4}}-\mathbf{N}$ & $\mathbf{N O}_{\mathbf{3}}-\mathbf{N}$ \\
\hline LUT & 2 & $7.91^{*}$ & $6.85^{*}$ & $17.17^{* *}$ & $26.57^{* *}$ & $2.80 \mathrm{~ns}$ & $1.41 \mathrm{~ns}$ \\
& & $(0.0208)$ & $(0.0283)$ & $(0.0033)$ & $(0.0010)$ & $(0.1381)$ & $(0.3143)$ \\
FAP (LUT) & 6 & $1.26 \mathrm{~ns}$ & $1.96 \mathrm{~ns}$ & $0.76 \mathrm{~ns}$ & $2.45 \mathrm{~ns}$ & $1.69 \mathrm{~ns}$ & $1.48 \mathrm{~ns}$ \\
& & $(0.3064)$ & $(0.1069)$ & $(0.6078)$ & $(0.0507)$ & $(0.1609)$ & $(0.2209)$ \\
CV (\%) & & 3.28 & 15.09 & 29.00 & 22.36 & 18.84 & 16.37 \\
\hline N.B: Symbols for significance levels: ${ }^{*}: P<0.05 ;{ }^{* *}: P<0.01 ;{ }^{* * *}: P<0.0001 ;$ ns: not significant). &
\end{tabular}


Table 2b: Mean values ( \pm standard errors, $n=4$ within fertilizer treatments and $n=12$ within land use types) of soil ( 0 -20 cm) chemical properties before planting the subsequent maize crop regarding fertilizer treatments for prior cotton crop and land use types.

\begin{tabular}{|c|c|c|c|c|c|c|c|}
\hline Land use types & $\begin{array}{l}\text { Fertilizer } \\
\text { treatments }\end{array}$ & $\begin{array}{l}\text { pH } \\
\text { (water) }\end{array}$ & $\begin{array}{l}\text { Total N } \\
\left(\mathrm{g} \mathrm{kg}^{-1}\right)\end{array}$ & $\begin{array}{l}\text { P-Bray 1 } \\
\left(\mathrm{mg} \mathrm{kg}^{-1}\right)\end{array}$ & $\begin{array}{l}\text { Exch. K } \\
\left(\text { cmol kg }^{+1}\right)\end{array}$ & $\begin{array}{l}\mathrm{NH}_{4}-\mathrm{N} \\
\left(\mathrm{mg} \mathrm{kg}^{-1}\right)\end{array}$ & $\begin{array}{l}\mathrm{NO}_{3}-\mathrm{N} \\
\left(\mathrm{mg} \mathrm{kg}^{-1}\right)\end{array}$ \\
\hline \multirow{4}{*}{$\begin{array}{l}\text { Egusi-cotton- } \\
\text { cotton-maize }\end{array}$} & $\mathrm{R}$ & $6.7 \pm 0.1$ & $1.6 \pm 0.1$ & $14.5 \pm 1.9$ & $0.2 \pm 0.0$ & $7.0 \pm 0.9$ & $7.4 \pm 0.3$ \\
\hline & M & $6.7 \pm 0.1$ & $1.4 \pm 0.1$ & $10.3 \pm 1.1$ & $0.2 \pm 0.0$ & $6.5 \pm 0.7$ & $6.1 \pm 0.0$ \\
\hline & Red & $6.8 \pm 0.2$ & $1.9 \pm 0.2$ & $12.1 \pm 2.1$ & $0.2 \pm 0.0$ & $6.9 \pm 0.3$ & $6.6 \pm 0.6$ \\
\hline & Mean & $6.7 \pm 0.1 \mathrm{~A}$ & $1.6 \pm 1.0 \mathrm{~B}$ & $12.3 \pm 1.0 \mathrm{~B}$ & $0.2 \pm 0.0 \mathrm{~B}$ & $6.8 \pm 0.4 \mathrm{~A}$ & $6.7 \pm 0.2 \mathrm{~A}$ \\
\hline \multirow{4}{*}{$\begin{array}{l}\text { Cotton-maize- } \\
\text { cotton-maize }\end{array}$} & $\mathrm{R}$ & $6.3 \pm 0.0$ & $2.0 \pm 0.0$ & $24.0 \pm 1.4$ & $0.4 \pm 0.0$ & $10.1 \pm 0.8$ & $8.1 \pm 0.8$ \\
\hline & M & $6.4 \pm 0.1$ & $2.2 \pm 0.2$ & $22.6 \pm 2.2$ & $0.5 \pm 0.0$ & $7.8 \pm 0.3$ & $8.0 \pm 0.7$ \\
\hline & Red & $6.4 \pm 0.0$ & $2.4 \pm 0.2$ & $21.7 \pm 2.2$ & $0.5 \pm 0.0$ & $7.4 \pm 1.1$ & $6.6 \pm 0.4$ \\
\hline & Mean & $6.3 \pm 0.0 \mathrm{~B}$ & $2.2 \pm 0.1 \mathrm{~A}$ & $22.8 \pm 1.1 \mathrm{~A}$ & $0.4 \pm 0.0 \mathrm{~A}$ & $8.4 \pm 0.6 \mathrm{~A}$ & $7.6 \pm 0.4 \mathrm{~A}$ \\
\hline \multirow{4}{*}{$\begin{array}{l}\text { Cassava-maize- } \\
\text { cotton-maize }\end{array}$} & $\mathrm{R}$ & $6.4 \pm 0.1$ & $2.2 \pm 0.1$ & $21.0 \pm 4.5$ & $0.2 \pm 0.0$ & $7.6 \pm 0.5$ & $7.8 \pm 0.9$ \\
\hline & M & $6.7 \pm 0.2$ & $2.1 \pm 0.2$ & $25.0 \pm 4.2$ & $0.2 \pm 0.0$ & $6.6 \pm 0.7$ & $7.0 \pm 0.3$ \\
\hline & Red & $6.6 \pm 0.1$ & $1.9 \pm 0.1$ & $18.3 \pm 2.9$ & $0.2 \pm 0.0$ & $7.0 \pm 0.4$ & $7.0 \pm 0.3$ \\
\hline & Mean & $6.6 \pm 0.1 \mathrm{AB}$ & $2.1 \pm 0.1 \mathrm{~A}$ & $21.4 \pm 2.2 \mathrm{~A}$ & $0.2 \pm 0.0 \mathrm{~B}$ & $7.0 \pm 0.3 \mathrm{~A}$ & $7.2 \pm 0.3 \mathrm{~A}$ \\
\hline
\end{tabular}

column, means followed by the same letters with the same characters are not significantly different $(P>0.05)$ (Student Newman-Keuls test)

$\mathrm{R}=$ Recommended $; \mathrm{M}=\mathrm{NPK}-\mathrm{SB}$ mixed with urea; Red. = Reduction of NPK-SB dose plus urea (split as the recommended practice). 
Table 3: Nested analysis of variance (F-values) of cotton fibre and seed yield and stalk mass regarding fertilizer treatments (FAP) and land use types (LUT). Figures in parentheses are probability of F-values.

\begin{tabular}{llll}
\hline Source of variation & $\mathbf{d f}$ & \multicolumn{2}{c}{ F-values of cotton yields } \\
\cline { 3 - 4 } & & Fibre and seed & Stalk mass \\
\hline LUT & 2 & $12.41^{* * *}$ & $4.62 \mathrm{~ns}$ \\
& & $(0.0074)$ & $(0.0610)$ \\
FAP (LUT) & 6 & $0.40 \mathrm{~ns}$ & $0.25 \mathrm{~ns}$ \\
& & $(0.8710)$ & $(0.9553)$ \\
CV (\%) & & 30.43 & 26.12 \\
\hline
\end{tabular}

Symbols for significance levels: ${ }^{* *} \mathrm{P}<0.01 ;$ ns not significant.

Table 4: Nested analysis of variance (F-values) of maize grain and stover yields regarding fertilizer treatments (FAP) and land use types (LUT). Figures in parentheses are probabilities of F-values.

\begin{tabular}{llll}
\hline Source of variation & df & Grain yield & Stover \\
\hline LUT & 2 & $14.47^{* * *}$ & $10.88^{*}$ \\
& & $(0.0051)$ & $(0.0101)$ \\
FAP(LUT) & 6 & $1.07 \mathrm{~ns}$ & $0.75 \mathrm{~ns}$ \\
& & $(0.4027)$ & $(0.6115)$ \\
CV $(\%)$ & & 19.92 & 19.89 \\
\hline N.B.; Symbols for significance levels: ${ }^{*} \mathrm{P}<0.05 ;{ }^{* *} \mathrm{P}<0.01 ;$ ns not significant.
\end{tabular}

Table 5a: Nested analysis of variance (F-values) of N, P and K concentration in the subsequent maize grain and stover and $\mathrm{N}, \mathrm{P}$ and $\mathrm{K}$ uptake regarding fertilizer treatments (FAP) and land use types (LUT). Figures in parentheses are probabilities of F-values.

\begin{tabular}{|c|c|c|c|c|c|c|c|c|c|c|}
\hline \multirow{2}{*}{$\begin{array}{l}\text { Source } \\
\text { of } \\
\text { variation }\end{array}$} & \multirow[t]{2}{*}{ df } & \multicolumn{3}{|c|}{$\begin{array}{c}\text { F-values of grain nutrient } \\
\text { concentration }\end{array}$} & \multicolumn{3}{|c|}{$\begin{array}{c}\text { F-values of stover nutrient } \\
\text { concentration }\end{array}$} & \multicolumn{3}{|c|}{$\begin{array}{c}\text { F-values of total nutrient } \\
\text { uptake }\end{array}$} \\
\hline & & $\mathbf{N}$ & $\mathbf{P}$ & $\mathbf{K}$ & $\mathbf{N}$ & $\mathbf{P}$ & $\mathbf{K}$ & $\mathbf{N}$ & $\mathbf{P}$ & $\mathbf{K}$ \\
\hline LUT & 2 & $\begin{array}{l}9.52^{*} \\
(0.0138)\end{array}$ & $\begin{array}{l}43.81^{* * *} \\
(0.0003)\end{array}$ & $\begin{array}{l}137.51^{* * * *} \\
(<0.0001)\end{array}$ & $\begin{array}{l}0.36 \mathrm{~ns} \\
(0.7113)\end{array}$ & $\begin{array}{l}5.73^{*} \\
(0.0406)\end{array}$ & $\begin{array}{l}13.53^{\text {** }} \\
(0.0060)\end{array}$ & $\begin{array}{l}11.74^{* *} \\
(0.0084)\end{array}$ & $\begin{array}{l}3.03 \mathrm{~ns} \\
(0.1234)\end{array}$ & $\begin{array}{l}1.56 \mathrm{~ns} \\
(0.2853)\end{array}$ \\
\hline $\begin{array}{l}\text { FAP } \\
(\text { LUT) }\end{array}$ & 6 & $\begin{array}{l}0.56 \mathrm{~ns} \\
(0.7602)\end{array}$ & $\begin{array}{l}0.87 \mathrm{~ns} \\
(0.5274)\end{array}$ & $\begin{array}{l}0.35 \mathrm{~ns} \\
(0.9064)\end{array}$ & $\begin{array}{l}1.94 \mathrm{~ns} \\
(0.1112)\end{array}$ & $\begin{array}{l}1.73 \mathrm{~ns} \\
(0.1515)\end{array}$ & $\begin{array}{l}1.10 \mathrm{~ns} \\
(0.3891)\end{array}$ & $\begin{array}{l}0.75 \mathrm{~ns} \\
(0.6159)\end{array}$ & $\begin{array}{l}1.60 \mathrm{~ns} \\
(0.1865)\end{array}$ & $\begin{array}{l}0.74 \mathrm{~ns} \\
(0.6250)\end{array}$ \\
\hline $\mathrm{CV}(\%)$ & & 11.06 & 23.61 & 17.18 & 16.09 & 31.90 & 16.83 & 22.41 & 29.88 & 26.41 \\
\hline
\end{tabular}


A.SAIDOU et al. / Int. J. Biol. Chem. 6(1): 365-378, 2012

Table 5b: Mean values ( \pm standard error, $n=4$ within fertilizer treatments and $n=12$ within land use types) of $N, P$ and $K$ concentration in the subsequent maize grain and straw and $\mathrm{N}, \mathrm{P}$ and $\mathrm{K}$ uptake regarding fertilizer treatments, land use types.

\begin{tabular}{|c|c|c|c|c|c|c|c|c|c|c|}
\hline \multirow[t]{2}{*}{ Land use types } & \multirow{2}{*}{$\begin{array}{l}\text { Fertilizer } \\
\text { treatments }\end{array}$} & \multicolumn{3}{|c|}{ Grain nutrient concentration $\left(\mathrm{g} \mathrm{kg}^{-1}\right)$} & \multicolumn{3}{|c|}{ Stover nutrient concentration $\left(\mathrm{g} \mathrm{kg}^{-1}\right)$} & \multicolumn{3}{|c|}{ Total nutrient uptake $\left(\mathrm{kg} \mathrm{ha}^{-1}\right)$} \\
\hline & & $\mathbf{N}$ & $\mathbf{P}$ & $\mathbf{K}$ & $\mathbf{N}$ & $\mathbf{P}$ & $\mathbf{K}$ & $\mathbf{N}$ & $\mathbf{P}$ & $\mathbf{K}$ \\
\hline \multirow{4}{*}{$\begin{array}{l}\text { Egusi-cotton-cotton- } \\
\text { maize }\end{array}$} & $\mathrm{R}$ & $17.6 \pm 0.3$ & $2.1 \pm 0.3$ & $2.9 \pm 0.1$ & $7.0 \pm 1.1$ & $0.9 \pm 0.3$ & $5.9 \pm 0.5$ & $77.6 \pm 9.7$ & $9.5 \pm 0.7$ & $35.2 \pm 5.2$ \\
\hline & M & $17.2 \pm 0.7$ & $3.1 \pm 0.8$ & $3.4 \pm 0.4$ & $7.7 \pm 0.3$ & $0.5 \pm 0.0$ & $5.1 \pm 0.7$ & $70.4 \pm 2.7$ & $8.7 \pm 1.2$ & $29.8 \pm 3.8$ \\
\hline & Red & $17.3 \pm 0.4$ & $3.0 \pm 0.5$ & $3.2 \pm 0.2$ & $8.6 \pm 0.8$ & $1.0 \pm 0.1$ & $5.6 \pm 0.5$ & $79.2 \pm 2.3$ & $11.4 \pm 1.0$ & $33.3 \pm 2.2$ \\
\hline & Mean & $17.4 \pm 0.3 \mathrm{~A}$ & $2.7 \pm 0.3 \mathrm{~B}$ & $3.2 \pm 0.2 \mathrm{~B}$ & $7.7 \pm 0.4$ & $0.8 \pm 0.1 \mathrm{~B}$ & $5.5 \pm 0.3 \mathrm{~B}$ & $75.7 \pm 3.3 \mathrm{~A}$ & $9.9 \pm 0.6 \mathrm{~A}$ & $32.8 \pm 2.2 \mathrm{~A}$ \\
\hline \multirow{4}{*}{$\begin{array}{l}\text { Cotton-maize-cotton- } \\
\text { maize }\end{array}$} & $\mathrm{R}$ & $15.4 \pm 0.9$ & $4.2 \pm 0.3$ & $2.9 \pm 0.2$ & $8.1 \pm 0.7$ & $1.4 \pm 0.1$ & $7.1 \pm 0.5$ & $56.6 \pm 8.2$ & $12.7 \pm 1.9$ & $29.5 \pm 2.2$ \\
\hline & M & $17.3 \pm 0.7$ & $3.7 \pm 0.4$ & $3.1 \pm 0.3$ & $7.3 \pm 0.2$ & $0.9 \pm 0.2$ & $8.0 \pm 0.6$ & $44.7 \pm 2.5$ & $7.6 \pm 0.8$ & $27.3 \pm 2.2$ \\
\hline & Red & $17.3 \pm 1.1$ & $3.8 \pm 0.3$ & $2.8 \pm 0.2$ & $9.3 \pm 0.4$ & $1.0 \pm 0.3$ & $9.0 \pm 0.9$ & $57.0 \pm 1.2$ & $9.0 \pm 1.3$ & $35.4 \pm 4.9$ \\
\hline & Mean & $16.7 \pm 0.5 \mathrm{~A}$ & $3.9 \pm 0.2 \mathrm{~A}$ & $2.9 \pm 0.1 \mathrm{~B}$ & $8.2 \pm 0.3$ & $1.1 \pm 0.1 \mathrm{AB}$ & $8.0 \pm 0.4 \mathrm{~A}$ & $52.7 \pm 3.1 \mathrm{~B}$ & $9.8 \pm 1.0 \mathrm{~A}$ & $30.7 \pm 2.0 \mathrm{~A}$ \\
\hline \multirow{4}{*}{$\begin{array}{l}\text { Cassava-maize-cotton- } \\
\text { maize }\end{array}$} & $\mathrm{R}$ & $15.3 \pm 1.2$ & $4.3 \pm 0.3$ & $4.0 \pm 0.2$ & $9.4 \pm 0.3$ & $1.6 \pm 0.2$ & $7.8 \pm 0.4$ & $60.9 \pm 4.9$ & $13.1 \pm 1.8$ & $36.0 \pm 2.2$ \\
\hline & M & $15.1 \pm 1.4$ & $4.6 \pm 0.5$ & $3.8 \pm 0.3$ & $7.8 \pm 0.1$ & $1.5 \pm 0.1$ & $7.4 \pm 0.5$ & $63.2 \pm 11.0$ & $15.6 \pm 3.1$ & $40.3 \pm 7.4$ \\
\hline & Red & $14.7 \pm 0.9$ & $4.4 \pm 0.3$ & $3.9 \pm 0.4$ & $7.8 \pm 1.1$ & $1.3 \pm 0.2$ & $7.1 \pm 0.5$ & $51.5 \pm 10.6$ & $11.6 \pm 1.5$ & $31.9 \pm 5.7$ \\
\hline & Mean & $15.0 \pm 0.6 \mathrm{~B}$ & $4.5 \pm 0.2 \mathrm{~A}$ & $3.9 \pm 0.2 \mathrm{~A}$ & $8.3 \pm 0.4$ & $1.5 \pm 0.1 \mathrm{~A}$ & $7.5 \pm 0.3 \mathrm{~A}$ & $58.5 \pm 5.1 \mathrm{~B}$ & $13.5 \pm 1.3 \mathrm{~A}$ & $36.1 \pm 3.1 \mathrm{~A}$ \\
\hline
\end{tabular}

Within column, means followed by the same letters with the same characters are not significantly different $(P>0.05)$ (Student Newman-Keuls test..

$\mathrm{R}=$ Recommended; $\quad \mathrm{M}=\mathrm{NPK}-\mathrm{SB}$ mixed with urea; $\mathrm{Red}=$ Reduction of NPK-SB dose plus urea (split as the recommended practice). 
Such situation could be explained by an improper crop management which has lead to nutrient losses due to removal through ammonia volatilization in the atmosphere and nitrate leaching or through run-off caused by the erratic and intense rainfall. However, as mentioned Oikeh et al. (2003), the risk for nitrate leaching is much more important in areas with higher rainfall intensities and lower water storage capacity as in the soil of the study area with sandy loamy characteristic. The relative importance of nutrient losses depends on the relationships between crop growth, water and nutrient dynamics, and soil acidity that can contribute to some nutrients ( $P$ and K) immobilization (Koné et al., 2010c). The high concentration of exchangeable $\mathrm{K}$ in the cotton-maize-cotton-maize land use type could be due to the importance of the aboveground biomass which is an important source of $\mathrm{K}$ in the traditional cropping system.

\section{Crops response to fertilizer treatments and} land use types

In general, adequate fertilization and proper crop rotation allow in some circumstances a sustained crop yield (Sauerborn et al., 2000 ; Waddington et al., 2007). These different crop rotation practices developed by the farmers are in the one hand, strategies of soil organic matter management and in the other hand, nutrient management strategy. Crop rotations are a central component in the development of resourceconserving farming, with optimal use of crops that contribute to soil fertility (Pretty, 1994). The present experiment showed that as the soil chemical properties, land use types affected much more both the cotton and subsequent maize yields than the fertilizer application practices. This may be due to several factors such as: amount and timing of $\mathrm{N}$ applied in cotton, crop characteristics (rooting system and nutrient requirement), farmer skills, and environmental factors (rainfall and soil characteristic).

The subsequent maize grain yields were moderately good because they were rather close to the maximum yield (4 to $6 \mathrm{t} \mathrm{ha}^{-1}$ ) that the DMR cultivars can reach on-station under controlled conditions. This substandard performance of the subsequent maize compared with the maximum yield as mentioned by Bolland and Gilkes (1990), may be due to continuous land cultivation which reduced considerably fertilizer residual effectiveness. Nevertheless, the overall maize grain yield harvested in our trial was quite similar with that (1.7 and $2.2 \mathrm{t}$ DM/ha) recorded by Sauerborn et al. (2000) after planting preceding cotton once and twice respectively on farmers' fields in northern Ghana. The authors explained this favourable preceding crop effect of cotton on maize yield by the different demand of the plant for nutrients. The low performance of the subsequence maize crop in the cotton-maizecotton-maize field could be attributed to the lack of nitrogen supply as supported by soil chemical parameters after the previous cotton and field observation (maize leaves sometimes presented yellowish colors). However, the favorable performance of maize crop in the egusi-cotton-cotton-maize system is due to the preceding cotton planted twice and the different demand for nutrient for these plants. Furthermore, Jones (1974) observed also favorable effect of cotton grown prior to maize as sole crops in Nigeria.

The relatively good performance of the subsequent maize crop in the cassava-maizecotton-maize field could be attributed to the characteristic of the cassava plant. In fact, prior cassava can possibly improve succeeding crop yields either by its relatively low nutrient extraction or by its ability to form symbiotic associations with arbuscular mycorrhizal fungi (Salami and Osonubi, 2002 ; Saïdou et al., 2009). High mycorrhizal 
inoculum potential at the start of the next cropping season might have major beneficial effects on P-uptake and growth of the subsequent crop (Goss and De Varennes, 2002; Saïdou et al., 2009).

The $\mathrm{N}: \mathrm{P}$ ratios of nutrients taken up indicated that $\mathrm{P}$ was relatively more limiting in the egusi-cotton-cotton-maize field $(\mathrm{N}: \mathrm{P}=$ 7.6) whereas, $\mathrm{N}$ was relatively more limiting in the cassava-maize-cotton-maize field $(\mathrm{N}: \mathrm{P}$ $=4.3)$. Furthermore, the overall average proportions $\mathrm{N}: \mathrm{P}: \mathrm{K}$ were $7.6: 1$ : 3.3, 5.4 : $1: 3.1$ and $4.3: 1: 2.7$ for egusi melon-cottoncotton-maize, cotton-maize-cotton-maize and cassava-maize-cotton-maize fields respectively which are closed to the ratio of $5.1: 1$ : 3.6 according to Saïdou et al. (2003) for local tall maize cultivars on ferralitic soil in southern Benin. Janssen et al. (1994) indicated an optimum ratio value of $7.8: 1: 5 \mathrm{~N}: \mathrm{P}: \mathrm{K}$ for hybrid maize. Our $\mathrm{N}: \mathrm{P}$ ratios suggest either differences between local maize and hybrid maize, or conditions were $\mathrm{N}$ was more limiting whenever $\mathrm{P}$ constraint was low. The low $\mathrm{N}: \mathrm{P}$ ratio in the cassava-maize-cottonmaize field is consistent with the hypothesis that the prior cassava had increased Pavailability in the system (Saïdou et al., 2009).

\section{Conclusion}

The experiments revealed the importance of land use types as major factor of production, and made clear that adaptation of fertilization technology package by farmers had similar effect with the recommendation rates of extension service, and must be taken into account by researchers and extensionists when developing technology for improvement. Nevertheless, in central Benin, it is suggested for sustainable soil fertility management to adopt adequate crop succession system while following recommended fertilizer application practice and good crop management practices (recommended crop density and crop residue management in order to reduce nutrient losses through leaching and run-off) on ferruginous soil. The study shows that, when cotton has been previously grown twice, it significantly improves the subsequent crop yield and the amount of nutrient taken up by the crop.

In order to make mineral fertilizer use more profitable to farmers, the recommendations should not focus on fertilization as a practice in isolation but should take account of farmer management skills, land use types, seasonality, labour availability, fertilizer availability and farmers' objectives.

\section{ACKNOWLEDGEMENTS}

The authors are grateful to the Dutch Government (DGIS), Wageningen University (INREF), FAO (Global IPM Facility) and the Government of the Republic of Benin for providing financial support to carry out the present study within the framework of the Convergence of Sciences Program: inclusive technology innovation processes for better integrated crop and soil management. We thank two anonymous reviewers for critically reading the manuscript and providing valuable input.

\section{REFERENCES}

Bolland MDA, Gilkes RJ. 1990. Cultivation reduces fertilizer residual effectiveness and affects soil testing for available phosphorus. Fert. Res., 24: 33-46.

Cochran WG. 1967. Statistical Methods $\left(6^{\text {th }}\right.$ edn). The Iowa State University Press: Des Moines, USA; 285-288.

Dubroeucq D. 1977. Carte pédologique de reconnaissance de la République Populaire du Bénin à 1/200.000. Notice explicative $N^{\circ} 66$ (3). Feuille de Savè. ORSTOM. Paris, France; 43.

Eijk van der D, Janssen HB, Oenema O. 2006. Initial and residual effects of fertilizer phosphorus on soil phosphorus and maize 
yields on phosphorus fixing soils: a case study in south-west Kenya. Agric. Ecos. Env., 116: 104-120.

Fok MAC, Djouara H, Koné M, Ballo D. 2000. Diversité des pratiques paysannes en zones cotonnières du Mali: portée et limites des gestions d'itinéraires techniques observées. In Rôle et Place de la Recherche pour le Développement des Filières Cotonnières en Evolution en Afrique. Proceedings of an international workshop held at Montpellier, Deguine Kok J-P, Gaborel MAC (eds). CIRAD France; 137-159.

Giller KE. 2002. Targeting management of organic resources and mineral fertilizers: can we match scientists' fantasies with farmers' realities? In Integrated Plant Nutrient Management in Sub-Saharan Africa: From Concept to Practice, Vanlauwe B, Diels J, Sanginga N, Merckx R (eds). CAB International: Wallingford, UK; 155-171.

Goss MJ, de Varennes A. 2002. Soil disturbance reduces the efficacy of mycorrhizal associations for early soybean growth and $\mathrm{N}_{2}$ fixation. Soil Biol. Biochem., 34: 1167-1173.

Janssen BH, Braakhekke WG, Catalan RL. 1994. Balanced plant nutrition: simultaneous optimization of environmental and financial goals. In Proceedings of an international workshop on the transactions of the $15^{\text {th }}$ World Congress of Soil Science held at Acapulco, Mexico Aguscalientes, Etchevers BJD (eds). Int. Soc. Soil Sci; 446-447.

Jones MJ. 1974. The effect of previous crop on yield and nitrogen response of maize at Samaru, Nigeria Exp. Agri., 10: 273279.

Koné B, Diatta S, Saïdou A, Akintayo I, Cissé B. 2009. Réponses des variétés interspécifiques du riz de plateau aux applications de phosphate en zone de forêt au Nigeria. Can. J. Soil Sci., 89: 555-565.

Koné B, Ettien JB, Amadji GL, Diatta S, Camara M. 2010a. Effets d'engrais phosphates de différentes origines sur la production rizicole pluviale des sols acides en zone de forêt semi-montagneuse sous climats tropicaux: Cas des hyperdystric ferralsols sous jachères en Côte d'Ivoire. Etude et Gestion des Sols, 17(1): 7-17.

Koné B, Oikeh S, Diatta S, Somado E, Kotchi V, Sahrawat KL. 2010b. Response of interspecifics and sativa upland rice to Mali phosphate rock and soluble phosphate fertilizer. Arch. Agro. Soil Sci., 57(4): 421-434.

Koné B, Yao-Kouamé A, Sorho F, Diatta S, Sié M, Ogunbayo A. 2010c. Long-term effect of Mali phosphate rock on the grain yield of interspecifics and sativa rice cultivars on acid soil in a humid forest zone of Côte d'Ivoire. Int. J. Biol. Chem. Sci., 4(3): 563-570.

Oikeh SO, Carsky RJ, Kling JG, Chude VO, Horst WJ. 2003. Differential N uptake by maize cultivars and soil nitrate dynamics under $\mathrm{N}$ fertilization in West Africa. Agric. Ecos. Env., 100: 181-191.

Pretty, N.J., 1994. Alternative systems of inquiry for a sustainable agriculture. IDS Bulletin 25(2): 37-48.

Saïdou A, Janssen BH, Temminghoff EJM. 2003. Effect of soil properties, mulch and NPK fertilizer on maize yields and nutrient budgets on ferralitic soils in southern Benin. Agric. Ecos. Env., 100: 265-273.

Saïdou A, Kuyper TW, Kossou D, Tossou R, Richards P. 2004. Sustainable soil fertility management in Benin: learning from farmers. NJAS - Wag. J. Life Sci., 52: 349-369. 
Saïdou A, Kossou D, Azontondé A, Hougni jachère sur la colonisation de la culture subséquente par les champignons endomycorhiziens : cas du système 'jachère' manioc sur sols ferrugineux tropicaux du Bénin. Int. J. Biol. Chem. Sci., 3(3): 587-597.

Salami OA, Osonubi O. 2002. Improving the traditional land use system through agrobiotechnology: a case study of adoption of vesicular arbuscular mycorrhiza (VAM) by resource-poor farmers in Nigeria. Technovation, 22: 725-730.

Sauerborn J, Sprich H, Mercer-Quarshie H. 2000. Crop rotation to improve agricultural production in Sub-Sahara Africa. J. Agro. Crop Sci., 184: 67-72.
D-GJM. 2009. Effet de la nature de la Soil Survey Staff. 1992. Keys to Soil Taxonomy $\left(5^{\text {th }}\right.$ edn). SMSS technical monograph $\mathrm{N}^{\circ} 19$. Blacksburg, Virginia: Pocahontas Press, Inc.

Vanlauwe B, Giller KE. 2006. Popular myths around soil fertility management in subSaharan Africa. Agric. Ecos. Env., 116: 34-46.

Waddington RS, Karigwindi J, Chifamba J. 2007. The sustainability of a groundnut plus maize rotation over 12 years on smallholder farms in the sub-humid zone of Zimbabwe. Afr. J. Agric. Res., 2(8): 342-348. 